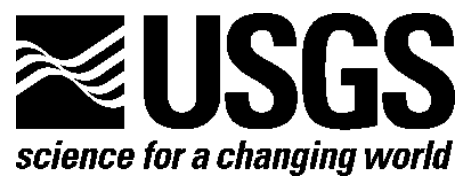

Prepared in cooperation with Wisconsin Cooperative Fishery Research Unit, Molecular Conservation Genetics Laboratory, College of Natural Resources, University of Wisconsin-Stevens Point

\title{
Validation of eDNA Markers for New Zealand Mudsnail Surveillance and Initial eDNA Monitoring at Mississippi River Basin Sites
}

By Christopher M. Merkes, Keith N. Turnquist, Christopher B. Rees, and Jon J. Amberg

Open-File Report 2015-1037

U.S. Department of the Interior

U.S. Geological Survey 


\title{
U.S. Department of the Interior SALLY JEWELL, Secretary
}

\section{U.S. Geological Survey Suzette M. Kimball, Acting Director}

\author{
U.S. Geological Survey, Reston, Virginia: 2015
}

For more information on the USGS-the Federal source for science about the Earth,its natural and living resources, natural hazards, and the environment-visit http://www.usgs.gov or call 1-888-ASK-USGS

(1-888-275-8747)

For an overview of USGS information products, including maps, imagery, and publications, visit http://www.usgs.gov/pubprod

Any use of trade, firm, or product names is for descriptive purposes only and does not imply endorsement by the U.S. Government.

Although this information product, for the most part, is in the public domain, it also may contain copyrighted materials as noted in the text. Permission to reproduce copyrighted items must be secured from the copyright owner.

Suggested citation:

Merkes, C.M, Turnquist, K.N, Rees, C.B, and Amberg, J.J, 2015, Validation of eDNA markers for New Zealand mudsnail surveillance and initial eDNA monitoring at Mississippi River Basin sites: U.S.

Geological Survey Open-File Report 2015-1037, 9 p., http://dx.doi.org/10.3133/ofr20151037. 


\section{Acknowledgments}

The authors would like to acknowledge John C. Nelson for generation of the map used in figure 1. Maureen Ferry coordinated the preparation for the study. Jean Unmuth, Michael Sorge, Kim Bogenschutz, Jason Euchner, James Amrhein, Rachel Peacher, David Wyffels, Matt O’Hara, Blake Bushman, Blake Ruebush, Kurt Rasmussen, Jacob Schweitzer, Mark Hazuga, Hnue Yang, Dave Farrow, and Amanda Perdzock collected the monitoring samples. This work was funded by the Mississippi Interstate Cooperative Resource Association and the Wisconsin Department of Natural Resources. 



\section{Contents}

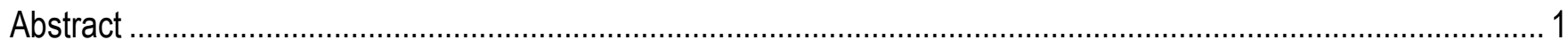

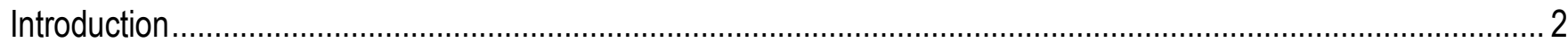

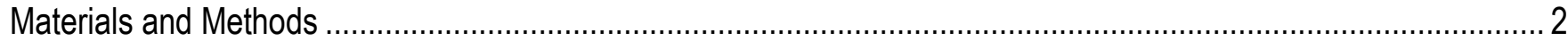

Marker Validation Sample Preparation..................................................................................................... 2

Monitoring Sample Collection .......................................................................................................

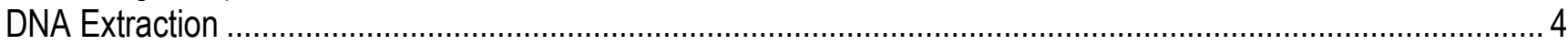

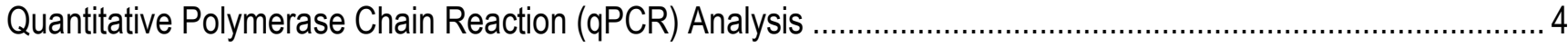

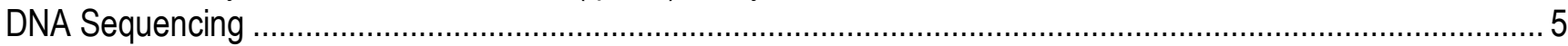

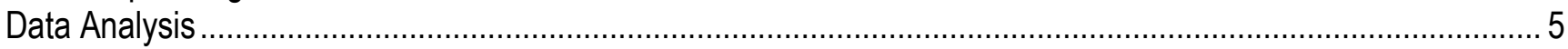

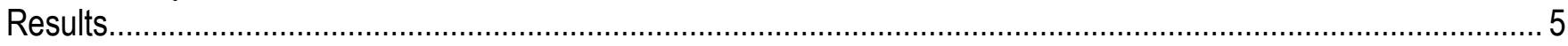

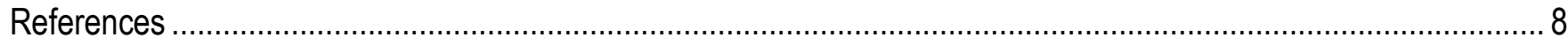

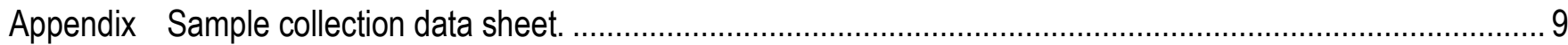

\section{Figures}

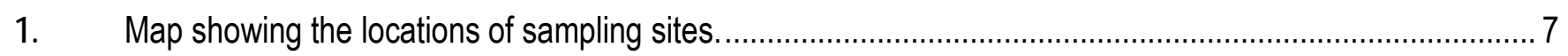

\section{Tables}

1. List of New Zealand mudsnail eDNA monitoring sites. ...................................................................... 3

2. Temperature profiles for quantitative polymerase chain reaction assays. ................................................ 4

3. Oligonucleotide sequences used for quantitative polymerase chain reaction assays................................. 4

4. Upper Midwest Environmental Sciences Center assay validation results................................................... 6

5. Molecular Conservation Genetics Laboratory assay validation results ................................................... 6

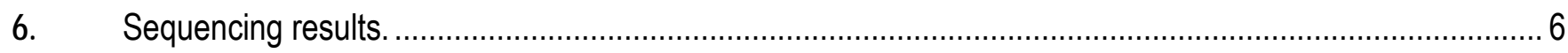

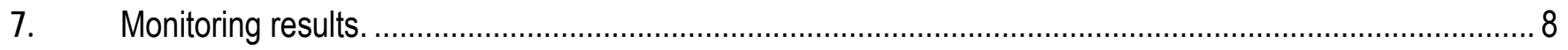




\section{Abbreviations}

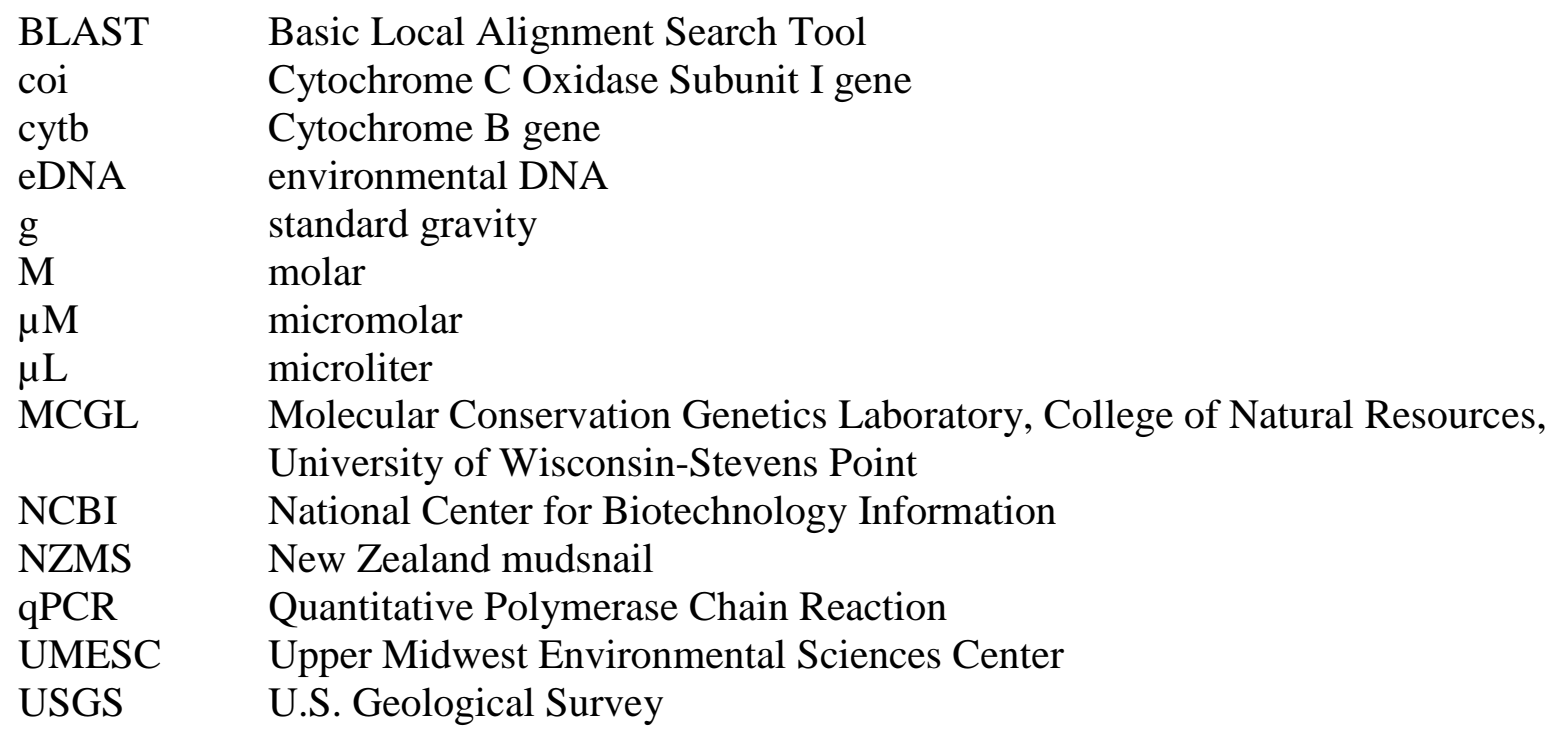

\section{Conversion Factors}

Inch/Pound to International System of Units

\begin{tabular}{|c|c|c|}
\hline Multiply & By & To obtain \\
\hline \multicolumn{3}{|c|}{ Length } \\
\hline foot (ft) & 0.3048 & meter $(\mathrm{m})$ \\
\hline yard (yd) & 0.9144 & meter $(\mathrm{m})$ \\
\hline \multicolumn{3}{|c|}{ Volume } \\
\hline barrel (bbl; petroleum, 1 barrel=42 gal) & 0.1590 & cubic meter $\left(\mathrm{m}^{3}\right)$ \\
\hline ounce, fluid (fl. oz) & 0.02957 & liter (L) \\
\hline \multicolumn{3}{|c|}{ Mass } \\
\hline ounce, avoirdupois (oz) & 28.35 & gram (g) \\
\hline
\end{tabular}

Temperature in degrees Celsius $\left({ }^{\circ} \mathrm{C}\right)$ may be converted to degrees Fahrenheit $\left({ }^{\circ} \mathrm{F}\right)$ as ${ }^{\circ} \mathrm{F}=\left(1.8 \times{ }^{\circ} \mathrm{C}\right)+32$.

Temperature in degrees Fahrenheit $\left({ }^{\circ} \mathrm{F}\right)$ may be converted to degrees Celsius $\left({ }^{\circ} \mathrm{C}\right)$ as ${ }^{\circ} \mathrm{C}=\left({ }^{\circ} \mathrm{F}-32\right) / 1.8$. 


\title{
Validation of eDNA Markers for New Zealand Mudsnail Surveillance and Initial eDNA Monitoring at Mississippi River Basin Sites
}

\author{
By Christopher M. Merkes ${ }^{1}$, Keith N. Turnquist², Christopher B. Rees ${ }^{1}$, and Jon J. Amberg ${ }^{1}$
}

\begin{abstract}
The performance of newly developed New Zealand mudsnail (Potamopyrgus antipodarum; NZMS) genetic markers for environmental (eDNA) analysis of water were compared across two laboratories. The genetic markers were tested in four quantitative polymerase chain reaction assays targeting two regions of the NZMS mitochondrial genome, specifically the cytochrome c oxidase subunit 1 (coi) and cytochrome b (cytb) genes. In a blind study, analysts tested each sample eight times with each assay. There were 10 expected-negative samples from the Black River in La Crosse, Wisconsin, 10 expected-positive samples from the Black Earth Creek in Black Earth, Wisconsin, and 10 known-positive samples from the Black River spiked with NZMS DNA. Previously extracted samples, kept at the Upper Midwest Environmental Sciences Center, were pooled by sample location and then equal quantities were distributed between the Upper Midwest Environmental Sciences Center and the Molecular Conservation Genetics Laboratory at the University of Wisconsin-Stevens Point for analysis. The assays tested were (1) the assay targeting cytb with a minor groove binder probe described by Goldberg and others (2013), (2) the cytb assay with a modified double-quenched probe, (3) an assay targeting coi with a double-quenched probe, and (4) a duplex reaction combining the modified cytb assay and the coi assay. Samples were considered positive for the presence of NZMS DNA when quantitative polymerase chain reaction amplification and probe signal was higher than the normalized threshold value above baseline fluorescence. For the duplex assay, samples were considered positive only when both probe signals were higher than the normalized threshold value above baseline fluorescence. Positive results were then confirmed by sequencing the products.

All four assays detected the DNA of NZMS in all expected-positive and known-positive samples in both labs. The modified cytb assay, the coi assay, and the duplex assay all failed to detect the DNA of NZMS in all expected-negative samples in both labs. The cytb assay, as described by Goldberg and others (2013), failed to detect the DNA of NZMS in all expectednegative samples for the Molecular Conservation Genetics Laboratory, but some reactions resulted in positive detection in late cycles for 9 of the 10 expected-negative samples at the Upper Midwest Environmental Sciences Center. Amplicons for expected-negative samples with
\end{abstract}

\footnotetext{
${ }^{1}$ U.S. Geological Survey

${ }^{2}$ University of Wisconsin-Stevens Point
} 
positive reactions were sent for sequencing, and none were confirmed as NZMS. Six amplicons failed to give readable sequences, and three gave sequences without similarity to any known sequence in GenBank. Amplicons from each assay for one representative positive sample were sequenced and identified as NZMS with greater than 99 percent identity.

The duplex assay was chosen as the most efficient assay and was used at the Upper Midwest Environmental Sciences Center to analyze triplicate samples from 29 streams in Wisconsin, 8 streams in Illinois, and 8 streams in Iowa. In order to verify results, additional triplicate samples were collected from two of the streams in Iowa and two of the streams in Wisconsin for analysis at the Molecular Conservation Genetics Laboratory. All samples at all sites were negative for NZMS DNA.

\section{Introduction}

Environmental DNA (eDNA) has been developed as an early detection and surveillance tool for New Zealand mudsnails (Potamopyrgus antipodarum; NZMS) in response to the growing invasion in the Great Lakes and western states (Goldberg and others, 2013). In October 2013, NZMS specimens were identified in benthic macroinvertebrate samples collected from Black Earth Creek, Dane County, Wisconsin during 2011 and 2012. This was the first known discovery of NZMS in the Midwest outside of the Great Lakes Basin and represents a significant threat to State and regional water resources. Following this discovery, additional benthic and eDNA samples were collected from Black Earth Creek. Preliminary results indicated that eDNA may be more accurate than traditional benthic sampling in the detection of NZMS in areas with low population densities.

In addition to the genetic marker developed by Goldberg and others (2013) targeting the cytochrome b mitochondrial gene (cytb), the Molecular Conservation Genetics Laboratory (MCGL) at University of Wisconsin - Stevens Point (UWSP) developed another marker for NZMS detection targeting the cytochrome c oxidase subunit I mitochondrial gene (coi). New markers that have been rigorously tested or published by other labs should be further validated before implementation in any monitoring program. This additional validation should be completed in multiple labs to demonstrate that the new markers are robust and produce repeatable results with different personnel and across different platforms.

A two-lab validation study was completed to compare the results of the newly developed markers following the procedures used to validate markers for eDNA surveillance of Asian carp (U.S. Geological Survey, U.S. Fish and Wildlife Service, U.S. Army Corps of Engineers, unpub. data, 2014). The validated markers were then used to test water samples collected from 45 sites in Wisconsin, Illinois, and Iowa for New Zealand mudsnail DNA.

\section{Materials and Methods}

\section{Marker Validation Sample Preparation}

Previously archived DNA extracts from Black River water samples collected in March, 2013, in La Crosse, Wisconsin were used as the expected-negative samples. Previously archived DNA extracts from Black Earth Creek water samples collected at South Valley Road in September, 2014, in Black Earth, Wisconsin were used as the expected-positive samples. Extracted DNA from captured NZMS was quantified at UMESC using the NZMS-cytb assay. Copy numbers were determined in 3 replicate reactions at each of 3 steps in a 10-fold serial 
dilution of starting material (9 total reactions), quantified from calibration with 2 replicate standard curves. Starting concentration was back-calculated by linear regression of the determined copy numbers and dilution factors from the 9 test reactions. Known concentrations at 2 levels (high $=10,000$ copies/microliter $(\mu L)$ and low $=100$ copies $/ \mu \mathrm{L}$ ) were then spiked into expected-negative extracts from Black River water samples. Extracts were pooled by type, and an analyst not otherwise associated with the study aliquoted $75 \mu \mathrm{L}$ samples for each lab, numbered at random and documented on a separate data sheet. Ten expected-negative samples, 10 expected-positive samples, 5 incurred-high samples, and 5 incurred-low samples were provided for each lab. Sample identity was unknown to all individuals associated with the study until the qPCR results were compiled.

\section{Monitoring Sample Collection}

Triplicate water samples were collected from 45 sites for monitoring (table 1). Measuring downstream from the road crossing at each site, survey flags were placed every 10 meters (m) on shore for $100 \mathrm{~m}$. Starting at the flag furthest downstream, 50 milliliters (mL) of water was collected from each $10 \mathrm{~m}$ block from the water surface targeting stream edges of low flow or areas of surface scum accumulation. The $50 \mathrm{~mL}$ water samples from the site were pooled into a $500 \mathrm{~mL}$ composite water sample that was then agitated before pipetting $15 \mathrm{~mL}$ subsamples into each of three $50 \mathrm{~mL}$ conical tubes containing $33 \mathrm{~mL}$ absolute ethanol and $1.5 \mathrm{~mL}$ of 3 molar sodium acetate for sample preservation. Preserved samples from all 45 sites were delivered to UMESC for testing. At four sites, three additional subsamples were taken from the composite sample for verification at the MCGL, as noted on table 1.

Waders were scrubbed with a brush, soaked in a 2 percent Virkon solution for 20 minutes, sprayed with bleach, and rinsed with municipal water between each site. Data sheets for ancillary information about the sample collection and site descriptions were filled out for each sample (Appendix A).

Table 1. List of New Zealand mudsnail eDNA monitoring sites. [Ill., Illinois; Wis., Wisconsin]

\begin{tabular}{|c|c|c|c|c|c|}
\hline Site & State & Site & State & Site & State \\
\hline Bloody Run $^{1}$ & Iowa & Sugar River at Colored Sands & Ill. & Namekagon River & Wis. \\
\hline French Creek & Iowa & Bear Creek & Wis. & Prairie River & Wis. \\
\hline North Bear Creek & Iowa & Big Green River & Wis. & Reads Creek & Wis. \\
\hline Paint Creek & Iowa & Big Spring Creek & Wis. & Rowan Creek & Wis. \\
\hline South Bear Creek & Iowa & Bishop Branch & Wis. & Rush River & Wis. \\
\hline Sny Magill Creek & Iowa & Camp Creek & Wis. & Spring Creek & Wis. \\
\hline Spring Branch & Iowa & Castle Rock Creek & Wis. & Story Creek ${ }^{1}$ & Wis. \\
\hline Waterloo Creek ${ }^{1}$ & Iowa & Dell Creek & Wis. & Sugar River at Frenchtown ${ }^{1}$ & Wis. \\
\hline Apple River at East Canyon Road & Ill. & Duncan Creek & Wis. & Timber Coulee Creek & Wis. \\
\hline Apple River at Townsend & Ill. & Gilbert Creek & Wis. & Trimbelle River & Wis. \\
\hline Fox River at Ayers Landing & Ill. & $\begin{array}{l}\text { Gordon Creek at Spring Creek } \\
\text { Road }\end{array}$ & Wis. & Trout Creek & Wis. \\
\hline $\begin{array}{l}\text { Fox River at Fox River Drive } \\
\text { Bridge }\end{array}$ & Ill. & Gordon Creek at State Route 39 & Wis. & Turton Creek & Wis. \\
\hline Kishwaukee River & Ill. & Kinnickinnic River & Wis. & West Branch Sugar River & Wis. \\
\hline Pecatonica River & Ill. & Mt. Vernon Creek & Wis. & West Fork Kickapoo & Wis. \\
\hline Rock River & Ill. & North Fork Bad Axe River & Wis. & Willow Creek & Wis. \\
\hline
\end{tabular}

${ }^{1}$ Additional replicate samples collected for results verification at the Molecular Conservation Genetics Laboratory. 


\section{DNA Extraction}

Samples were centrifuged at 5,000 times standard gravity (g) for 30 minutes, and the supernatant was decanted. DNA in the remaining pellets was extracted using the commercially available gMax Mini Genomic DNA kit (IBI Scientific; Peosta, Iowa) following the manufacturer's guidelines with a final elution volume of $100 \mu \mathrm{L}$.

\section{Quantitative Polymerase Chain Reaction (qPCR) Analysis}

The presence of New Zealand mudsnail DNA was determined using quantitative polymerase chain reaction (qPCR) assays. All assays were run in eight replicate reactions using $20 \mu \mathrm{L}$ total volume with $1 \mu \mathrm{L}$ of template DNA. All assays used 2x SensiFAST Probe No-ROX master mix (Bioline; Taunton, Mass.) to supply $\mathrm{pH}$ buffer, DNA polymerase, $\mathrm{Mg}^{2+}$ coenzyme, deoxynucleotide triphosphates, and PCR adjuvants at $1 \mathrm{x}$ proprietary final concentration. The NZMS-cytb assay used 0.4 micromolar $(\mu \mathrm{M})$ final concentration of each primer and $0.2 \mu \mathrm{M}$ final probe concentration. The NZMS-cytb-mod, NZMS-coi, and NZMS-cytb-coi assays used $0.2 \mu \mathrm{M}$ final concentration of each primer and $0.4 \mu \mathrm{M}$ final concentration of each probe. The temperature profiles used are listed in table 2, and the oligonucleotide sequences used are listed in table 3. Assays were run on a Mastercycler Realplex 2 (EppendorfNA; Hauppage, N.Y.) at the Upper Midwest Environmental Sciences Center and on a MX3005P qPCR system (Stratagene; La Jolla, Calif.) at the Molecular Conservation Genetics Laboratory.

Table 2. Temperature profiles for quantitative polymerase chain reaction assays.

[NZMS, New Zealand mudsnail; ${ }^{\circ} \mathrm{C}$, degrees Celsius; sec., seconds; min., minutes]

\begin{tabular}{lcc}
\hline Step & NZMS-cytb assay & $\begin{array}{c}\text { NZMS-cytb-mod, NZMS-coi, } \\
\text { NZMS-cytb-coi assays }\end{array}$ \\
\hline Initial Denaturation & $95^{\circ} \mathrm{C}-2$ min. & $95{ }^{\circ} \mathrm{C}-2$ min. \\
\hline Amplification and & 50 cycles of: & 55 cycles of: \\
Quantification & $94^{\circ} \mathrm{C}-60$ sec. & $95^{\circ} \mathrm{C}-60$ sec. \\
& $60^{\circ} \mathrm{C}-60$ sec. & $52^{\circ} \mathrm{C}-30$ sec. \\
& $72^{\circ} \mathrm{C}-30$ sec. \\
\hline Hold & $4{ }^{\circ} \mathrm{C}$ - Indefinitely & $4{ }^{\circ} \mathrm{C}-$ Indefinitely \\
\hline
\end{tabular}

Table 3. Oligonucleotide sequences used for quantitative polymerase chain reaction assays. [Oligo, oligonucleotide; NZMS, New Zealand mudsnail]

\begin{tabular}{lll}
\hline Oligo ID & Sequence & Assay(s) used \\
\hline NZMS-CYTB-F & TGTTTCAAGTGTGCTGGTTTAYA & NZMS-cytb, NZMS-cytb-mod, \\
NZMS-CYTB-R & CAAATGGRGCTAG-coi \\
& & NZMS-cytb, NZMS-cytb-mod, \\
NZMS-cytb-coi \\
NZMS-CYTB-PROBE & 6FAMCCTCGACCAATATGTAAAT/MGB & NZMS-cytb \\
NZMS-CYTB-EXT & 56-FAM/ATYCCTCGA/ZEN/CCAATATGTAAATAAATAC/3IABkFQ & NZMS-cytb-mod, \\
& & NZMS-cytb-coi \\
NZMS-COI-F & CTCCTGCTTTCTTTACCTGTCT & NZMS-coi, NZMS-cytb-coi \\
NZMS-COI-R & ACCAGAATAAGTGCTGATAAAGGAT & NZMS-coi, NZMS-cytb-coi \\
NZMS-COI-FAM & 56-FAM/ATTTCGATC/ZEN/CGTTAATAGTATTGTAATAGCYCC/3IABkFQ & NZMS-coi \\
NZMS-COI-JOE & 56-JOE/ATTTCGATC/ZEN/CGTTAATAGTATTGTAATAGCYCC/3IABkFQ & NZMS-cytb-coi \\
NZMS-gBlock & TATGGCTGGCTACTTCGTGCCCTACACGCAAATGGGGCTAGTTGATTC & All Asssays \\
& TTTATTTGTATTTATTTACATATTGGTCGAGGAATATATTATGGATCAT & \\
& ATGTAAACCAGCACACTTGAAACATTGGAGTAATTCTTCTCGTTTTAA & \\
& CTATGGCCACTGCTTTTTAGGTTATGTTTCTGTTAAAATTACAGCTAT & \\
& TTTACTCCTGCTTTCTTTACCTGTCTTAGCAGGGGCTATTACAATACTA & \\
& TTAACGGATCGAAATTTCAATACTGCTTTTTTTGATCCTGCTGGGGGTG & \\
& GTGATCCTATCCTTTATCAGCACTTATTCTGGTTTTCGGACACCCAGA & \\
\hline
\end{tabular}




\section{DNA Sequencing}

The products resulting from at least one positive reaction from an expected-positive sample and any positive reactions from expected-negative samples were sequenced for each assay at MCGL. The qPCR products were purified using the MultiScreen PCR $\mu 96$ filter plate (Millipore Corporation, Billerica, Mass.) according to the manufacturer's protocol. The purified PCR products were sequenced using the BigDye Terminator v3.1 Cycle Sequencing Kit (Applied Biosystems, Inc., Foster City, Calif.). Each cycle sequencing reaction mixture contained 0.75x proprietary concentration BigDye buffer (MCLAB, San Francisco, Calif.), 0.75 $\mu \mathrm{L}$ BDX64 (BigDye enhancing buffer, MCLAB), $0.32 \mu \mathrm{M}$ forward primer (NZMS-COI-F or NZMS-CYTB-F [table 3]), $0.25 \mu \mathrm{L}$ BigDye v3.1 (Applied Biosystems Inc.), and $1.5 \mu \mathrm{L}$ of cleaned PCR product in a final volume of $10 \mu \mathrm{L}$. Cycle sequencing reactions were purified with the Montage SEQ96 Sequencing Reaction Cleanup Kit (Millipore), and sequenced on an Applied Biosystems 3730xl DNA Analyzer (Applied Biosystems, Inc.) at the Molecular Conservation Genetics Laboratory. The sequences were manually edited in Geneious version 8.0.5 (Drummond and others, 2012) and the species identities were determined with the National Center for Biotechnology Information (NCBI) nucleotide database and Megablast search algorithm (Altschul and others, 1997, as implemented in Geneious version 8.0.5). The highest percent sequence similarity obtained from the Basic Local Alignment Search Tool (BLAST) search (minimum percent match $=95.0$ percent) was used to identify the likely source species for each qPCR sample sequenced.

\section{Data Analysis}

Baseline fluorescence was automatically normalized for all qPCR replicates within each plate by the software used at each laboratory. Threshold values were manually set to the same level across all plates for each assay targeting the start of the exponential phase of the amplification plots. Positive detection was determined if the normalized fluorescence rose above the threshold values. Samples were considered positive for New Zealand mudsnail DNA with the single marker assays (NZMS-cytb, NZMS-cytb-mod, NZMS-coi) if any of the eight replicate reactions had positive detection. Samples were considered positive for New Zealand mudsnail DNA in the duplex assay (NZMS-cytb-coi) if both dyes had positive detection independently in any of the eight replicate reactions. Only the duplex assay was used to analyze the monitoring samples. Samples that had positive detection but failed sequence confirmation were considered negative for New Zealand mudsnail DNA.

The number of detections in known-positive, expected-positive, and expected-negative samples were compared across the four assays. Assays were considered validated if detection probability was equal to or higher than that of the published NZMS-cytb assay for positive samples with equal or less detections among negative samples.

\section{Results}

In total, 20 samples positive for New Zealand mudsnail DNA and 10 samples negative for New Zealand mudsnail DNA were analyzed using four qPCR assays at each of the two labs. All four assays at both labs detected New Zealand mudsnail DNA in all 20 positive samples (tables 4,5). All four assays at both labs did not detect or were considered negative for New Zealand mudsnail DNA in all 10 expected-negative samples after sequencing confirmation (tables 4,5 ). The sequences obtained are shown in table 6 . All assays were considered validated, 
and the duplex assay (NZMS-cytb-coi) was selected as the preferred analysis for NZMS monitoring because of the increased efficiency associated with analyzing two markers simultaneously.

Table 4. Upper Midwest Environmental Sciences Center assay validation results. (Please see accompanying file NZMS-Table4.xlsx)

Table 5. Molecular Conservation Genetics Laboratory assay validation results.

(Please see accompanying file NZMS-Table5.xlsx)

Table 6. Sequencing results.

(Please see accompanying file NZMS-Table6.xlsx)

Triplicate water samples collected from 45 sites were analyzed at UMESC in eight replicate reactions using the NZMS-cytb-coi assay with additional replicate water samples collected from four sites being verified at the MCGL (table 1). All samples were negative for New Zealand mudsnail DNA. The results were verified in the four samples at the MCGL (fig. 1, table 7). All positive controls detected New Zealand mudsnail DNA and all negative controls did not detect New Zealand mudsnail DNA. 


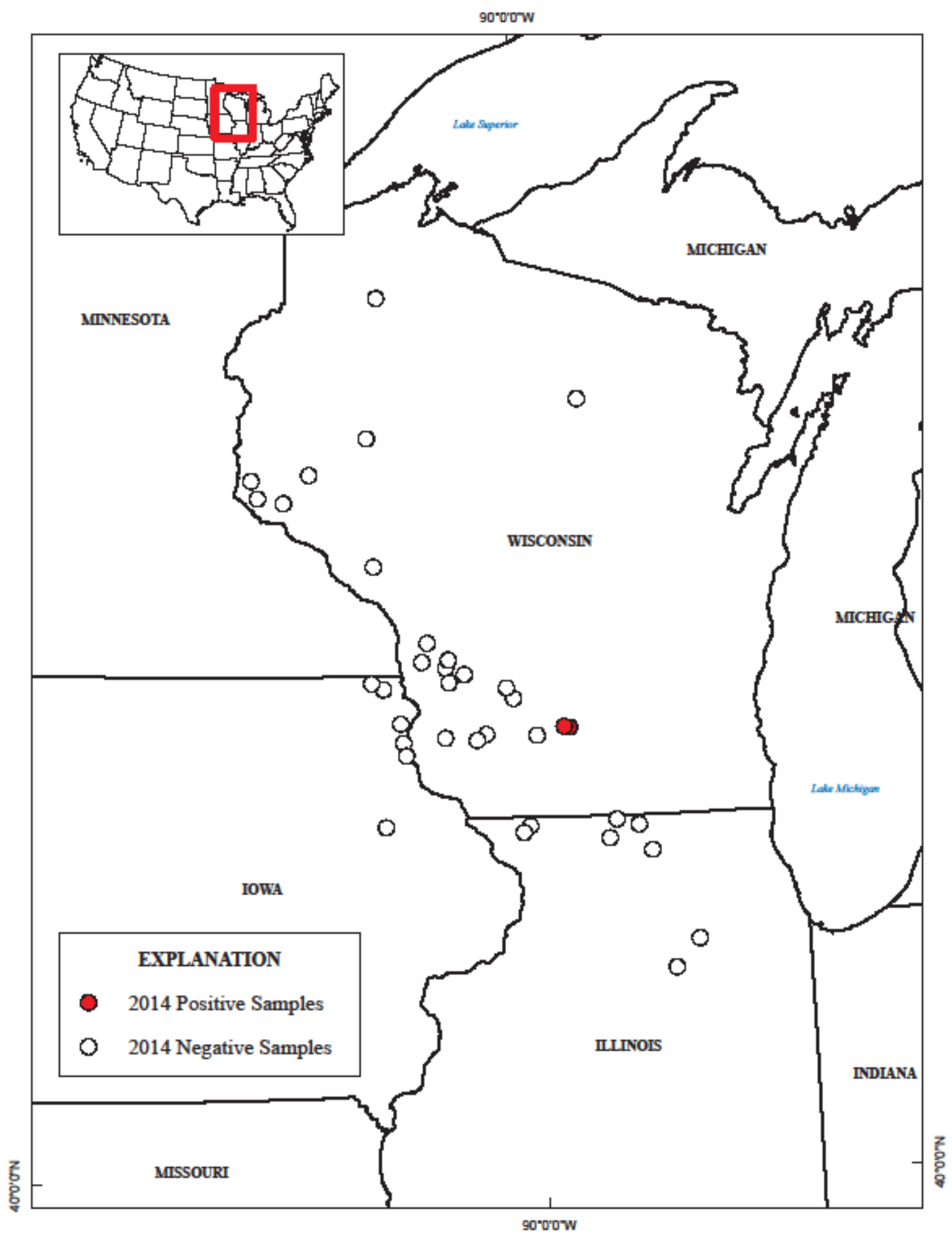

Figure 1. Map showing the locations of sampling sites. White circles, sites that tested negative for New Zealand mudsnail DNA; red circles, original infestation sites. Sites not shown because global positioning system coordinates were not recorded: North Bear Creek, lowa; South Bear Creek, lowa; Dell Creek, Wis.; Gordon Creek at Spring Creek Rd., Wis.; Gordon Creek at State Route 39, Wis.; Mt. Vernon Creek, Wis.; Rowan Creek, Wis.; Spring Creek, Wis.; Story Creek, Wis.; Sugar River at Frenchtown, Wis.; West Branch Sugar River, Wis. 
Table 7. Monitoring results.

(Please see accompanying file NZMS-Table7.xlsx)

\section{References}

Altschul, S.F., Madden, T.L., Schäffer, A.A., Zhang, J., Zhang, Z., Miller, W., and Lipman, D.J., 1997, Gapped BLAST and PSI-BLAST_A new generation of protein database search programs: Nucleic Acids Research, v. 25, p. 3389-3402.

Drummond, A.J., Ashton, B., Buxton, S., Cheung, M., Cooper, A., Duran, C., Field, M., Heled, J., Kearse, M., Markowitz, S., Moir, R., Stones-Havas, S., Sturrock, S., Thierer, T., and Wilson, A., 2012, Geneious ver. 8.0.5: Biomatters, Ltd., available from http://www.geneious.com/.

Goldberg, C.S., Sepulveda, A., Ray, A., Baumgardt, J., Waits, L.P., 2013, Environmental DNA as a new method for early detection of New Zealand mudsnails (Potamopyrgus antipodarum): Freshwater Science, v. 32, no. 3, p. 792-800. 


\section{Appendix Sample collection data sheet.}

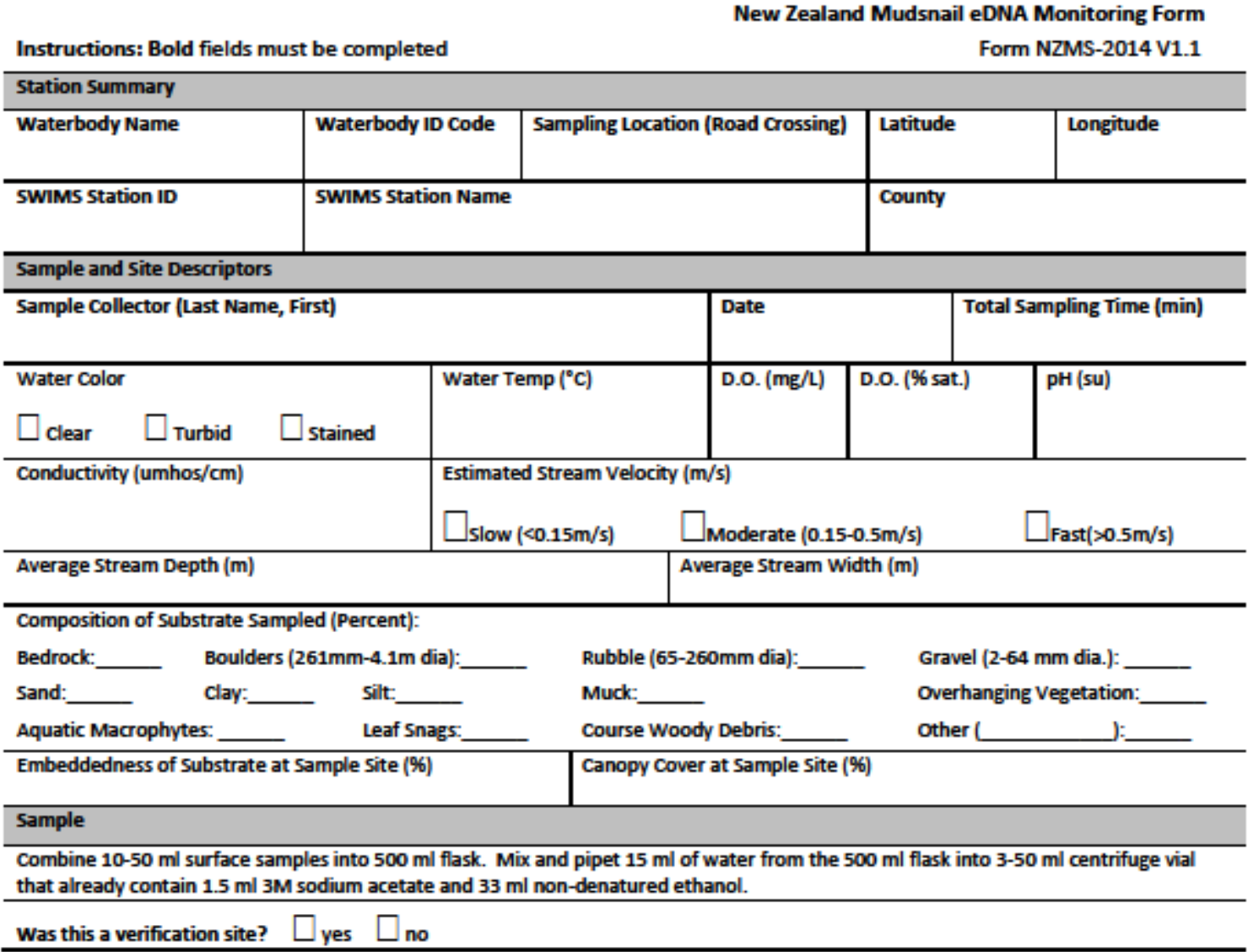

Comments:

Send sample to:

All samples:

\section{Chris Merkes}

Upper Midwest Environmental Sciences Center

United States Geological Survey

2630 Fanta Reed Road

La Crosse, WI 54603

\author{
$10 \%$ verification samples: \\ Keith Turnquist \\ College of Natural Resources \\ University of Wisconsin-Stevens Point \\ 800 Reserve Street \\ Stevens Point, W1 54481
}

Disinfection:

Prior to sampling, spray equipment with bleach to remove DNA. After completing a reach, soak waders and equipment in a $2 \%$ Virkon solution in a tub for $\mathbf{2 0}$ minutes to disinfect. Then spray or soak waders and all equipment with bleach to remove any DNA and avoid false positives. Rise equipment with municipal water after disinfecting. Clean gloves should be used for each reach. 


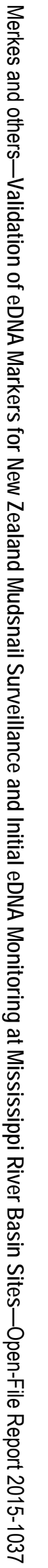

